\title{
CASH DIVIDEND EX-DAY ANOMALY AND AN INVESTMENT STRATEGY
}

\author{
DOI: 10.17261/Pressacademia.2020.1177 \\ JEFA- V.7-ISS.1-2020(2)-p.9-21
}

Eyup Kadioglu ${ }^{1}$, Faruk Bostanci ${ }^{2}$, Nurcan Ocal ${ }^{3}$

${ }^{1}$ Ghent University, Department of Economics, Sint-Pietersplein 5 Ghent 9000 Belgium. eyup.kadioglu@ugent.be, eyup.kadioglu@gmail.com, ORCID: 0000-0001-7836-868X

2Independent Researcher, Genclik Cd. No.9, Cankaya, Ankara, Turkey.

faruk.bostanci@gmail.com , ORCID: 0000-0002-4151-7618

${ }^{3}$ Capital Markets Board of Turkey, Investor Compensation Center, Cankaya, Ankara, Turkey. nurcan.ocal@spk.gov.tr, ORCID: 0000-0002-5870-2844

To cite this document

Kadioglu, E., Bostanci, F., Ocal, N. (2020). Cash dividend ex-day anomaly and an investment strategy. Journal of Economics, Finance and Accounting (JEFA), V.7(1), p.9-21.

Permemant link to this document: http://doi.org/10.17261/Pressacademia.2020.1177

Copyright: Published by PressAcademia and limited licenced re-use rights only.

\section{ABSTRACT}

Purpose - This study examines the effect of ex-day of cash dividend on stock returns using data of 2.266 cash dividends of 422 listed companies from Borsa Istanbul for the period 1997-2018.

Methodology - The event study analysis applied for the event windows opened from the $t_{-30}$ to $t_{+30}$, and the market-adjusted model was used to calculate abnormal returns.

Findings- It is found that there are positive abnormal returns before ex-day, as prices significantly start to rise at least 22 days before cash dividend ex-day and reach to the its' highest level on the ex-day and then decrease in the following days.

Conclusion- Based on our findings, it is found that price anomaly caused by ex-day of cash dividend can be used as a two-step mutually exclusive investment strategy. In the first step, buying firms' shares which are decided to distribute dividend per share more than $\% 100$, twelve days before ex-day and selling them at the end of ex-dividend day provides on average $2.96 \%$ abnormal return addition to cash dividend over the 13 days, in the second step, short selling the same stocks at the end of ex-day and buying back them on seven days after ex-dividend day provides on average $1.51 \%$ abnormal return over 7 days. Using these investment strategies, it is possible to get $4.47 \%$ return over market index return in addition to $100 \%$ cash dividend per share over the period of 20 days by utilising ex-dividend day anomaly.

Keywords: Cash dividend; ex dividend day effect; price anomaly; market micro structure, investment strategy JEL Codes: G10; G12; G14; G35

\section{NAKIT TEMETTÜ DAĞITMA ANOMALISI VE BIR YATIRIM STRATEJISI}

\section{ÖZET}

Amaç-Bu çalışmada, 1997-2018 döneminde Borsa İstanbul'da işlem gören 422 farklı şirket tarafından gerçekleştirilen 2.266 adet nakit temettü dağıtım sürecinde ilan edilen temettüsüz günün 30 gün öncesi ve sonrasındaki hisse senedi getirileri incelenmiştir.

Metodoloji- Analizlerimizde, olay analizi yöntemi, $t-30$ ile $t+30$ döneminde açılan olay pencereleri için uygulanmış olup, anormal getirileri bulmak amacıyla uyarlanmış piyasa modelinden faydalanılmışıı.

Bulgular-Anormal getirinin temettüsüz gün öncesindeki 22'nci günden başlayarak önemli ölçüde arttığı, artışın temettüsüz günün sonuna kadar devam ettiği ve izleyen günlerde de negatif anormal getirinin oluştuğu bulunmuştur.

Sonuç- Çalışmamızdaki bulguların, birbirinden bağımsız iki aşamalı yatırım stratejisi olarak kullanılabileceği sonucuna ulaşılmışır. Hisse başına \%100 oranından daha fazla temettü dağıtacağını açıklayan şirket hisselerinin, ilk aşamada temettüsüz gününün 12 gün öncesinde satın alınması ve temettüsüz günün sonunda satılması durumunda, hisseye verilen nakit kâr payına ek olarak 13 günde ortalama \%2,96 anormal getiri elde edildiği ve ikinci aşamada temettüsüz günün sonunda aynı hisse senedinin açığa satılması ve 7 gün sonra geri satın alınması durumunda 7 günde ortalama \%1,51 anormal getiri elde edildiği hesaplanmıştır. Dolayısıyla, nakit temettü dağıtım sürecindeki anomaliden yararlanarak hisse başına $\% 100$ 'ün üzerinde nakit temettüye ek olarak 20 günde ortalama $\% 4,47$ oranında piyasa endeks getirisinin üzerinde getiri sağlanabilmektedir.

Anahtar Kelimeler: Temettü; temettüsüz dönem etkisi; fiyat anomalisi; piyasa mikro yapısı; yatırım stratejisi JEL Kodları: G10; G12; G14; G35 


\section{GiRiş}

Kâr dağıtım kararı ile birlikte hangi tarihe kadar satın alınan payların temettü hakkına sahip olacağı bilgisi de kamuya açıklanmaktadır. Literatürde "ex-dividend day" olarak adlandırılan "temettüsüz gün"e kadar satın alınan hisse senetleri temettü alabilmekte, temettüsüz gün ve sonrasında alınan hisse senetlerinin açıklanan temettüyü alma hakkı olmamaktadır. Temettüsüz günden itibaren piyasada işlem gören hisse senedinin fiyatı nakit kâr payını içermediği için daha önceki güne göre (doğal olarak) düşük olmaktadır. Söz konusu düşüklük, teorik olarak, hisse başına temettü tutarı kadar olması gerekirken, yapılan çalışmalarda bu farkın hisse başına temettü tutarından daha az olduğu gözlemlenmektedir. Konuya ilişkin yapılan çalışmalarda teorik fiyat ile temettüsüz günde piyasada ortaya çıkan fiyat arasında olması gerekenden daha az fark olduğu tespiti genel olarak yapılırken, bu farkın sebebine ilişkin farklı görüş ve hipotezler öne sürülmektedir. Diğer taraftan bu farklıı̆̆ın ve bu farklılığa ilişkin fiyatın uyarlanma sürecinin sadece temettüsüz günde değil öncesi ve sonrasında da devam ettiği gözlemlenmektedir.

Temettüsüz gün etrafında ortaya çıkan anormal getiri tartışmaları Elton and Gruber (1970) ile başlamış olup, konuyu Woolridge (1983) aşırı tepki hipoteziyle, Boyd and Jagannathan (1994), Kalay (1982), Karpoff and Walkling (1988), Koski (1996) ve R. Michaely and Vila (1996) kısa vadeli işlem hipoteziyle, Dhatt, Kim, and Mukherji (1994), Dhatt, Kim, and Mukherji (1996), Eades, Hess, and Kim (1984), Frank and Jagannathan (1998), ve Lakonishok and Vermaelen (1986) mikro yapı bakış açısıyla, Dupuis (2019) likidite bakış açısıyla, Hartzmark and Solomon (2019) bedava temettü yanılgısı hipoteziyle, Roni Michaely and Vila (1995) dinamik temettü müşteri tercihleri hipoteziyle ve diğer pek çok araştırmacı vergi temelli yaklaşımlarla (Barclay, 1987; Elton \& Gruber, 1970; Elton, Gruber, \& Blake, 2005; Graham \& Kumar, 2006; Graham, Michaely, \& Roberts, 2003; Naranjo, Nimalendran, \& Ryngaert, 2000; Whitworth \& Rao, 2010) açıklamaya çalışmıştır.

Türkiye için temettüsüz gün anomalisini inceleyen çalışma sayısı oldukça sınırlı olup, temettü ile piyasa fiyatı ilişkisini inceleyen çalışmaların büyük bir kısmı kâr dağııımının açıklama etkisine yöneliktir. En son 2003 yılı ve öncesine ait verilerle çalışma yapıldığı dikkate alındığında, bu çalışmanın gerekli olduğu; literatüre, yatırımcılara ve portföy yöneticilerine katkı sağlayacağı düşünülmektedir. Çalışmamızda temettüsüz gün civarında anormal getirinin varlığını tespit etmek tek amaç olarak belirlenmemiş, buna ek olarak söz konusu anormal getirinin bir yatırım stratejisi olarak kullanılıp kullanılamayacağı değerlendirilmiştir. Ayrıca yatırım stratejisi geliştirme kapsamında kâr payı büyüklüğünün bir fark yaratıp yaratmadığı da araştırılmıştır.

Temettüsüz gün civarında anormal getirinin varlığını analiz etmek üzere Borsa İstanbul A.Ş.'de (Borsa, Borsa İstanbul) işlem gören 422 farklı şirketin 1997-2018 yılları arasında dağıtmış olduğu 2.266 adet temettü verisi kullanılmıştır. Örneklemimiz tüm popülasyonun \%91'ini kapsamakta olup, 85 tane gözlem aynı gün bedelli ve/veya bedelsiz sermaye artırımı olması nedeniyle analiz dışında bırakılmıştır. Anormal getiri analizlerini yapmak üzere temettüsüz gün merkezde olmak üzere her bir hisse senedi için 61 günlük düzeltilmiş kapanış fiyatı ve aynı günlere ait olmak üzere Borsa İstanbul'da tüm hisse senetlerini içeren XUTUM endeksi kullanılmıştır. Analizlerimizde, olay analizi yöntemi, $t_{-30}$ ile $t_{+30}$ döneminde açılan olay pencereleri için uygulanmış olup, anormal getirileri bulmak amacıyla uyarlanmış piyasa modelinden faydalanılmıştır.

Yapılan analizlerde temettüsüz gün öncesi 30 günlük sürede $\left(\left(t_{-30}-t_{0}\right]\right)$ ortalama kümülatif olarak \%3,09 oranında Borsa endeksi üzerinde getiri sağlanmaktadır. Temettüsüz gün sonrası 30 günlük sürede $\left(\left(t_{0}-t_{+30}\right]\right)$ ise ortalama kümülatif olarak $\% 0,92$ oranında Borsa endeksi altında getiri elde edilmektedir. Toplam 60 günlük olay penceresinde ([ $\left.\left.t_{-30}-t_{+30}\right]\right)$ ortalama kümülatif olarak \%2,17 oranında Borsa endeksi üzerinde getiri sağlanmaktadır. Temettüsüz güne yaklaştıkça gün başına düşen ortalama kümülatif anormal getiri artmaktadır. Temettüsüz günün hisse senedi getirileri üzerindeki etkisini ölçmek üzere olay gününden önceki 30 gün ve sonraki 30 günü kapsayan olay pencerelerinin tamamında t istatistiği \%1 düzeyinde anlamlıdır.

Bulguların değerlendirilmesi sonucunda 422 farklı hisse senedinin 1997-2018 yılları arasında dağıtmış olduğu 2.266 adet nakit temettünün hisse senedi getirileri üzerindeki temettüsüz gün etkisi yarattığı ve daha yüksek temettü dağıtımının daha yüksek getiri sağladığı sonucundan yola çıkarak birbirinden bağımsız iki aşamalı yatırım stratejisinin geliştirilmesinin mümkün olduğu sonucuna ulaşımıştır. Hisse başına \%100 oranından daha fazla temettü dağıtacağını açıklayan şirket hisselerinin, ilk aşamada temettüsüz gününün 12 gün öncesinde satın alınması ve temettüsüz günün sonunda satılması durumunda, hisseye verilen nakit kâr payına ek olarak 13 günde ortalama \%2,96 anormal getiri elde edildiği ve ikinci aşamada temettüsüz günün sonunda aynı hisse senedinin açığa satılması ve 7 gün sonra geri satın alınması durumunda 7 günde ortalama \%1,51 anormal getiri elde edildiği hesaplanmıştır. Dolayısıyla, nakit temettü dağıtım sürecindeki anomaliden yararlanarak hisse başına \%100'ün üzerinde nakit temettüye ek olarak 20 günde ortalama $\% 4,47$ oranında piyasa endeks getirisinin üzerinde getiri sağlanabilmektedir.

Çalışmamızın devamı şu şekilde düzenlemiştir. İkinci bölümde, literatür taramasına, konuya ilişkin teorilere ve bugüne kadar yapılan ampirik çalışmaların sonuçlarına; üçüncü bölümde, çalışmamızda kullanılan veri seti ve ampirik analizin metodolojisine; dördüncü bölümde, analiz sonucunda elde edilen bulgulara yer verilmiştir. Son bölümde ise, çalışmanın sonuçları özetlenmiştir. 


\section{LITERATÜR ÖZETi}

Mali yııının kapanmasının ardından, şirketlerin finansal tablolarının açıklanmasından sonra, genel kurul toplantısından önce, geride bırakılan yılda oluşan kârın nasıl dağııılacağına ilişkin bir yönetim kurulu kararı kamuya açıklanmaktadır. Ayrıca, genel kurul kararıyla kesinleşen kâr payının, hangi tarih itibarıyla sahip olunan paylara dağıtılacağı bilgisi de kamuya açıklanmaktadır. Dolayısıyla, kamuya açıklanan temettü kararının bilgi içeriği piyasaya günler öncesinden yansımaktadır. Kâr payına hak kazanma bitim tarihinden sonra yani temettüsüz gün ve sonrasında satın alınan payların fiyatının dağıtılan temettü tutarı kadar daha düşük olması gerekmektedir. Ancak, yapılan araştırmalarda kâr payı içeren hisse fiyatı ile kâr payı içermeyen hisse fiyatı arasında dağıtılan temettü tutarından daha az bir fark olduğu görülmektedir.

Temettü hakkının bittiği ilk işlem günü olan temettüsüz günün hisse fiyatına olan etkisi tartışmaları Elton and Gruber (1970) ile başlamıştır. Temettü hak bitiminden hemen sonra fiyatın temettü tutarından daha az düştüğü ortaya konmuş olup, her şeyin sabit kaldığı bir ortamda söz konusu farkın olmaması gerektiği yine onlar tarafından ileri sürülmüştür.

Chottiner and Young (1971) tarafından ABD Newyork borsası için temettüsüz gün etkisi üzerine yapılmış olan çalışmada piyasa açııış fiyatının teorik fiyattan daha yüksek olduğu görülmüştür. Foster and Vickrey (1978)'nde yaptığı çalışmada ise açılış fiyatı yerine kapanış fiyatlarını kullanmış olup, temettüsüz günün öncesinde ve sonrasında anormal getirinin olduğunu ortaya koymuş; ancak, temettüsüz gün için anormal getiri bulamamıştır. Benzer şekilde Woolridge (1983) ABD hisse senetleri için hem kapanış hem açılış fiyatları üzerinden temettüsüz gün etkisini analiz etmiş ve piyasa fiyatının teorik fiyattan ortalama \%1 daha yüksek olduğunu bulmuştur. Woolridge (1983) söz konusu anormal getirinin 15 gün önce başlayıp 90 güne kadar devam ettiğini ortaya koymuştur.

Benzer şekilde Grinblatt, Masulis, and Titman (1984) tarafından yapılan çalışmada temettüsüz günün öncesinde ve sonrasında anormal getiri olduğu ortaya konulmuştur. ABD piyasası için bir diğer çalışma olan Paudel, Silveri, and Wu (2019) tarafından yapılan çalışmada da yine benzer bulgulara ulaşılmıştır. Japonya hisse senetleri için Dhatt et al. (1994) tarafından yapılan çalışmada daha zayıf olmakla birlikte benzer sonuçlara ulaşılmıştır. Dhatt et al. (1996) tarafından önceki çalışmalarının devamı olarak Kore hisse senetleri için yapılan çalışmada ise temettüsüz günün öncesinde ve sonrasında anormal getiri bulunmuştur. Vietnam piyasası için yapılan çalışmada ise temettüsüz günün öncesi ve sonrasında sırasıyla pozitif ve negatif anormal getiri bulunmuştur (Tran, 2017). Tayvan piyasası için Jiang and Huang (2009) tarafından yapılan araştırmada da benzer sonuçlara ulaşılmıştır. Yapılan bazı çalışmalarda ise temettüsüz gün civarında anormal getiri bulunamamıştır (Papaioannou, Travlos, \& Tsangarakis, 2000).

Yapılan teorik ve ampirik çalışmalarda, temettüsüz gün nedeniyle ortaya çıkan fiyat anomalisi veya anormal getirileri, kâr payı veya sermaye kazancının farklı vergilendirilmesi, temettünün bilgi içeriği, temettü yanılgısı hipotezi, aşırı tepki hipotezi, dinamik temettü müşteri tercihleri hipotezi veya piyasa mikro yapısı ile açıklanmaya çalışıldığı görülmektedir.

Chottiner and Young (1971)'e göre piyasa fiyatının kendini tam olarak uyarlayamaması nedeniyle piyasa açılış fiyatı teorik fiyattan daha yüksek olmaktadır. Bu açıklama Woolridge (1983) tarafından da kabul görmüştür. Woolridge (1983) çalışmasıyla finans literatürüne davranışsal bakış açısını getirmiş ve aşııı tepki hipotezini ortaya atmıştır. Bu hipoteze göre yatırımcılar kâr payı dağıtan şirketin geleceği hakkında aşırı olumlu bir görüşe sahip olduklarından temettüsüz gün yaklaştıkça alım yönünde baskı oluşturarak pozitif anormal getiriye neden olmaktadırlar. Tam bilgiye sahip rasyonel yatırımcılar da temettüsüz gün sonrasında payları satmaları nedeniyle negatif anormal getiriye neden olmaktadırlar. Boyd and Jagannathan (1994), Kalay (1982), Karpoff and Walkling (1988), Koski (1996) ve R. Michaely and Vila (1996) tarafından ileri atılan kısa vadeli işlem hipotezine göre temettüsüz gün anomalisi marjinal kısa-vadeli işlem yapan yatırımcıların işlem maliyetlerinden kaynaklanmaktadır.

Temettüsüz günde piyasa fiyatının teorik fiyattan daha yüksek olmasına piyasa uzmanlarının alım ve satım emirlerini yeteri kadar hızlı ayarlayamamasının neden olduğu da öne sürülmektedir (Dubofsky, 1992). Her ne kadar Dhatt et al. (1994) ve Dhatt et al. (1996) tarafından yapılan çalışmalarda temettüsüz gün öncesinde anormal getiri olduğu ortaya konmuşsa da bu durumun piyasanın mikro yapısından daha çok temettüye özel bir durum olduğu belirtilmiştir. Diğer taraftan, Eades et al. (1984), Frank and Jagannathan (1998) ile Lakonishok and Vermaelen (1986) temettüsüz günde ortaya çıkan fiyat anomalisini piyasanın mikro yapısına bağlamaktadırlar. Likiditenin, temettüsüz günde ortaya çıkan fiyat anomalisinin nedeni olduğu Dupuis (2019) tarafından ileri sürülmüştür. Ainsworth, Fong, Gallagher, and Partington (2018) ise alım ve satım emirleri arasındaki dengesizliğin temettüsüz gün öncesinde anormal getiriye sebep olduğunu ileri sürmüştür. Paudel et al. (2019) tarafından yapılan çalışmada da vergi bazlı veya kısa vadeli işlem hipotezlerinden çok, bedava temettü yanılgısı hipotezinin destek gördüğü ileri sürülmüştür. Bedava temettü yanılgısı hipotezine göre yatırımcılar, kâr payı ve fiyat değişikliklerini birbirinden bağımsız olarak değerlendirmektedirler (Hartzmark \& Solomon, 2019).

Roni Michaely and Vila (1995) tarafından ileri sürülen dinamik temettü müşteri tercihleri hipotezine göre temettüsüz günde görülen fiyat anomalisi tüm yatırımcıların işlemleri sonucunda ortaya çıkan dinamik bir fiyat oluşum süreci olarak 
görülmektedir. Le, Yin, and Zhao (2019) tarafından Avustralya için yapılan çalışmada temettüsüz günde ortaya çıkan fiyat anomalisinin dinamik temettü müşteri tercihleri hipoteziyle açıklanabileceği iddia edilmiştir. Diğer taraftan, temettüsüz günde görülen teorik fiyat piyasa fiyatı farkı, Jakob and Whitby (2017)'a göre hisse fiyatından, Mortal, Paudel, and Silveri (2017)'e göre ise piyasa yapısından etkilenmektedir.

Türkiye için konuyla ilgili ilk çalışma Oran and Özkan (2001) tarafından yapılmış olup, çalışmada temettüsüz günde ortaya çıkan piyasa ve teorik fiyat farkının vergi kaynakıı hipotezlerle açıklanamayacağı ileri sürülmüştür. Günalp, Kadioglu, and Kılıç (2010) ile Kadioglu, Telçeken, and Öcal (2015) tarafından yapılan çalışmalarda, temettünün açıklama etkisinin negatif anormal getiriye neden olduğu dikkate alındığında vergi temelli yaklaşımların temettüsüz günde ortaya çıkan piyasa ve teorik fiyat farkını açıklamada yetersiz kalmaktadır. Yilmaz and Gulay (2006) tarafından 1995-2003 dönemi için Borsa İstanbul'da işlem gören şirketler için yapılan çalışmada temettüsüz günde ve bu güne birkaç gün kala pozitif anormal getiri ve sonrasında ise negatif anormal getirinin varlığı ortaya konmuştur.

Türkiye için yapılan diğer çalışmalarda esas olarak kâr payının açıklama etkisi analiz edilmiştir (Aydogan \& Muradoglu, 1998; Batchelor \& Orakcioglu, 2003; Kirbaş, 2018; Muradoğlu \& Aydoğan, 2003).

\section{VERI VE METODOLOJI}

\subsection{Veri}

Çalışmada kullanılan 1997-2018 dönemine ait kapanış fiyatı, Borsa endeksi ve temettü verileri Matriks Metastsock programı aracılı̆ııla Borsa İstanbul'dan alınmıştır. Matriks Metastsock programı aracılığıyla alınan veriler temettü ve sermaye artırımlarına göre düzeltilmiş veriler olduğundan verilerin manuel olarak düzeltilmesine gerek kalmamıştır. Ayrıca, temettüyle aynı güne denk gelen bedelli veya bedelsiz sermaye artırımı bulunan 85 gözlem örneklemimizden elimine edilmiştir. Borsa'da işlem gören şirketler dağıtabilir kârlarının; 1995-2003 döneminde \%50'sini, 2004 ve 2005 yıllarında \%30'nu, 2006-2007-2008 yıllarında \%20'sini nakit veya hisse olarak dağıtmak zorundayken, 2009 yılından sonra bu kural kaldırılmıştır.

Araştırmadaki örneklemimiz, Borsa'da işlem gören 422 farklı şirketin 1997-2018 yılları arasında dağıttığı 2.266 adet nakit temettü verisini kapsamaktadır. Veri setimizde, temettüsüz günün 30 gün öncesi ve sonrasını kapsayacak şekilde, hisse senetlerine ait düzeltilmiş kapanış fiyatları ile Borsa İstanbul'un tüm hisse senetlerinden oluşan BISTTUM kapanış endeks fiyatı yer almaktadır. 2.266 adet temettüsüz gün, temettüsüz gün öncesi ve sonrası 30'ar gün olmak üzere toplam 61 günlük anormal getirinin hesaplanması için 96.036 adet hisse fiyatı ve endeks verisi kullanılmıştır.

Tablo 1'de Borsa'da işlem gören şirket sayısı ile 1997-2018 yılları arasında dağıtılan temettülere ilişkin özet verilere yer verilmiştir.

Tablo 1: Borsa'da İşlem Gören Şirket Sayısı ve Hisse Başına Dağıtılan Temettüye i̇lişkin Tanımlayıcı İstatistikler

\begin{tabular}{lccccccc}
\hline YIl & $\begin{array}{c}\text { Borsa'daki } \\
\text { ŞinketSaysi }\end{array}$ & $\begin{array}{c}\text { Temettü } \\
\text { Ödeme } \\
\text { Saysi }\end{array}$ & $\begin{array}{c}\text { Ömeklemdeki } \\
\text { TemettïÖdeme } \\
\text { Saysi }\end{array}$ & $\begin{array}{c}\text { OrtalamaHisse } \\
\text { BaşnaTemettï } \\
\text { (TL) }\end{array}$ & $\begin{array}{c}\text { Standart } \\
\text { Sapma }\end{array}$ & $\begin{array}{c}\text { MaksimumHisse } \\
\text { BaşnaTemettü } \\
\text { (TL) }\end{array}$ & $\begin{array}{c}\text { MinimumH Hisse } \\
\text { BaşnaTemettü(TL) }\end{array}$ \\
\hline 1997 & 258 & 113 & 87 & 0,89 & 1,10 & 6,40 & 0,0600 \\
1998 & 277 & 104 & 69 & 0,85 & 0,96 & 6,00 & 0,0705 \\
1999 & 285 & 87 & 60 & 0,69 & 0,91 & 6,00 & 0,0500 \\
2000 & 315 & 84 & 68 & 1,51 & 6,42 & 53,19 & 0,0500 \\
2001 & 310 & 74 & 61 & 1,28 & 4,80 & 37,57 & 0,0298 \\
2002 & 288 & 66 & 58 & 1,13 & 2,33 & 14,47 & 0,0697 \\
2003 & 285 & 73 & 65 & 0,97 & 2,29 & 15,65 & 0,0112 \\
2004 & 297 & 58 & 52 & 0,76 & 3,12 & 22,68 & 0,0121 \\
2005 & 306 & 100 & 95 & 0,85 & 3,03 & 26,15 & 0,0024 \\
2006 & 322 & 105 & 100 & 0,98 & 2,59 & 21,00 & 0,0164 \\
2007 & 327 & 114 & 110 & 1,34 & 4,30 & 30,20 & 0,0071 \\
2008 & 326 & 120 & 115 & 0,98 & 2,49 & 19,22 & 0,0100 \\
2009 & 325 & 95 & 93 & 0,82 & 2,02 & 14,00 & 0,0112 \\
2010 & 350 & 110 & 109 & 0,58 & 1,44 & 9,57 & 0,0160 \\
2011 & 373 & 119 & 116 & 0,46 & 0,98 & 6,58 & 0,0067 \\
2012 & 395 & 125 & 121 & 0,73 & 1,88 & 14,50 & 0,0047 \\
2013 & 388 & 149 & 139 & 0,56 & 1,51 & 16,42 & 0,0085
\end{tabular}




\begin{tabular}{llllllll}
2014 & 422 & 141 & 135 & 0,51 & 0,95 & 5,62 & 0,0010 \\
2015 & 416 & 176 & 174 & 0,59 & 1,24 & 10,00 & 0,0085 \\
2016 & 405 & 160 & 154 & 1,09 & 4,22 & 47,81 & 0,0020 \\
2017 & 399 & 160 & 153 & 0,64 & 1,37 & 12,00 & 0,0038 \\
2018 & 409 & 154 & 132 & 1,24 & 3,30 & 26,00 & 0,0046 \\
\hline Top. & & $\mathbf{2 . 4 8 7}$ & $\mathbf{2 . 2 6 6}$ & $\mathbf{0 , 8 5}$ & $\mathbf{2 , 6 7}$ & $\mathbf{5 3 , 1 9}$ & $\mathbf{0 , 0 0 1 0}$ \\
\hline
\end{tabular}

Tablo 1'den de görüleceği üzere Borsa'da işlem gören 422 şirket 1997-2018 yılları arasında 2.487 kez temettü dağıtmış olup, bu temettülerden 85 tanesi aynı gün bedelli veya bedelsiz kâr payı dağıtılması nedeniyle örnekleme alınmamış, 136 tanesi ise sağlıklı bir şekilde fiyat verilerine ulaşılamaması nedeniyle örneklem dışında bırakıımıştır. Bu çerçevede, örnekleme alınan 2.266 adet temettü dikkate alındığında 21 yıllık dönemde ortalama hisse başına 0,85 TL temettü dağıtıldığı, en düşük temettünün hisse başına 0,001 TL ve en yüksek temettünün ise hisse başına 53,19 TL olduğu görülmektedir. Tablo 1'den de anlaşılacağı üzere Borsa'da işlem gören firmaların yaklaşı \%30'u temettü dağıtmakta olup, Fatemi and Bildik (2012)'in de ileri sürdüğü üzere yıllar itibariyle Borsa'da hisse başına temettünün azaldığı görülmektedir.

\subsection{Metodoloji}

Çalışmada temettüsüz günün fiyat üzerindeki etkisinin varlığı, yani dağıtılacak temettünün miktarı ve zamanı bilinmesine rağmen hisse senedi fiyatında bir anomalinin oluşup oluşmadığı veya bu durumun anormal getiriye neden olup olmadığı olay penceresi yöntemi ile analiz edilmiştir.

Illk defa Dolley (1933) tarafından kullanılan, Ball and Brown (1968) ve Armitage (1995) tarafından formülize edilen olay penceresi yöntemi belirli bir olayın hisse senedi fiyatı veya işlem hacmi üzerinde etkisi olup olmadığının araştırılmasında sıkça kullanılmaktadır. Bu yöntem; temettünün açıklama etkisini tespit etmek üzere Pettit (1972), Brown and Warner (1980), Aharony and Swary (1980), Woolridge (1982), Asquith and Mullins (1983), Akhigbe and Madura (1996), Miletić (2011) ve Kadioglu et al. (2015) tarafından; kâr açıklamalarının hisse fiyatına olan etkisini analiz etmek üzere Dennis and McConnell (1986) tarafından; içerden öğrenenlerin ticaretini araştırmak üzere Sivakumar and Waymire (1994), Gregory, Matatko, and Tonks (1997), Hillier and Marshall (2002) tarafından; makroekonomik olayların açıklanmasını incelemek üzere Basdas and Oran (2014) tarafından; arbitraj imkanlarını ve piyasadaki likiditeyi incelemek üzere Ghadhab (2018) tarafından; bir haberin açıklanmasının etkisini ölçmek üzere Dimpfl (2011), Yildiz, Karan, and Pirgaip (2017), Piccoli, Chaudhury, Souza, and da Silva (2017), Marshall, McCann, and McColgan (2018) ve Kočenda and Moravcová (2018) tarafından ve temettü dağıtmanın etkisini incelemek üzere Yilmaz and Gulay (2006), Al-Yahyaee (2014) ve Chowdhury and Sonaer (2016) tarafından kullanılmıştır.

Analizlerde kullanılan veriler bölünme, birleşme, sermaye artırımları ve kâr paylarına göre düzeltilmiş veri olduğundan hisse kapanış fiyatının veya Borsa endeksi kapanış verisinin manuel olarak düzeltilmesine gerek kalmamıştır. Aşağıdaki (1) numaralı denklem hisse senedi i'nin $t$ günündeki kapanıştan kapanışa olan günlük getirisini bulmak için kullanılmıştır.

$$
R_{i t}=\left(P_{i t}-P_{i t-1}\right) / P_{i t-1}
$$

Burada $R_{i t}$ hisse senedi i'nin $t$ günündeki kapanıştan kapanışa olan günlük getirisini, $P_{i t}$ hisse senedi i'nin $t$ günündeki düzeltilmiş kapanış fiyatını, $P_{i t-1}$ hisse senedi $i$ nin $t-1$ günündeki düzeltilmiş kapanış fiyatını göstermektedir. Piyasa endeksinin günlük getirisi de aynı formülden yararlanarak Borsa İstanbul BISTTUM endeksinin ardışık günlerdeki kapanış değerleri üzerinden hesaplanmıştır.

Aşağıdaki (2) numaralı denklem hisse senedi i'nin $t$ günündeki anormal getirisini hesaplamak için kullanılmıştır.

$$
A R_{i, t}=R_{i, t}-\left(\alpha_{i}+\beta R_{m, t}\right)
$$

(2) numaralı formüldeki $A R_{i, t}$ hisse senedi i'nin $t$ günündeki anormal getirisini ve $R_{m, t}$ piyasa endeksinin $t$ günündeki getirisini ifade etmektedir. Analizlerde anormal getiriyi bulmak için uyarlanmış piyasa modeli tercih edilmiş olup, diğer bazı çalışmalarda riske göre uyarlanmış piyasa modeli kullanılabilmektedir. Uyarlanmış piyasa modeli, hissenin piyasaya göre risk seviyesini ölçen $\beta$ katsayının "1" yani hisse senedinin piyasa ile aynı riske sahip olduğunu ve sabit terim katsayının da " 0 " olduğunu kabul etmektedir. Diğer taraftan, riske göre uyarlanmış piyasa modeli geçmişte nötr bir döneme ait verilerden yararlanarak beta ve sabit terim katsayısını hesaplamakta ve her bir hisse senedinin kendine has risk durumunu dikkate almaktadır. Ancak yapılan çalışmalarda, bu iki modelin farklı sonuçlar vermediği yani birinin diğerinden daha üstün olmadığı ortaya konmuştur (Armitage, 1995; Asquith \& Mullins, 1983; Aydogan \& Muradoglu, 1998; Brown \& Warner, 1980; Campbell, Lo, \& MacKinlay, 1997; Charest, 1978; Woolridge, 1982). Hatta, Marsh (1979) riske göre uyarlanmış piyasa modelinin daha sınırlı veri kullanıyor olması dolayısıyla bu modelinin istatistiksel etkinliği azalttığını ileri sürmüştür. 
Çalışmamızda kullanılan olay penceresi analizlerinde ortalama anormal getiriler ve ortalama kümülatif anormal getiriler için aşağıdaki (3), (4), (5) numaralı denklemler kullanılmıştır.

$$
\begin{gathered}
A A R_{t}=\frac{1}{N} \sum_{i=1}^{N} A R_{i, t} \\
C A R_{i}=\sum_{t=T_{1}}^{T_{2}} A R_{i, t} \\
C A A R=\frac{1}{N} \sum_{i=1}^{N} C A R_{i}
\end{gathered}
$$

Burada; $A A R_{t} N$ adet hisse senedinin $t$ günündeki ortalama anormal getirisini ve $C A R_{i}$ ise hisse senedi i'nin $T=t_{1}-T=t_{2}$ olay penceresindeki kümülatif anormal getirisini ifade etmektedir. $C A A R$ ise $N$ adet hisse senedinin $T=t_{1}-T=t_{2}$ olay penceresindeki ortalama anormal kümülatif getirisini göstermektedir.

Olay penceresindeki ortalama kümülatif anormal getirinin istatiksel olarak sıfırdan farklı olup olmadığı aşağıdaki denklemler aracılığıyla test edilmiştir.

$$
\begin{gathered}
t_{C A A R=\sqrt{N}} \frac{C A A R}{s_{C A A R}} \\
s_{C A A R}^{2}=\frac{1}{N-1} \sum_{i=1}^{N}\left(C A A R_{i}-\overline{C A A R}\right)^{2}
\end{gathered}
$$

(6) numaralı denklemdeki $s_{C A A R}$ ortalama kümülatif anormal getirilerin standart sapmasını göstermekte olup, standart sapmanın hesaplanmasına ilişkin formül ise denklem (7) de verilmiştir.

\section{AMPIRIK SONUÇLAR}

Şekil 1 temettüsüz gün merkezde olmak üzere bu günün 30 gün öncesi ve 30 gün sonrası için açılan olay pencereleri boyunca ortalama kümülatif anormal getiri, ortalama anormal getiri ve işlem hacmini göstermekte olup, temettüsüz gün "t00" olarak sembolize edilmiştir.

\section{Şekil 1: Temettüsüz Gün Öncesi ve Sonrası Getiriler ve İşlem Hacmi}

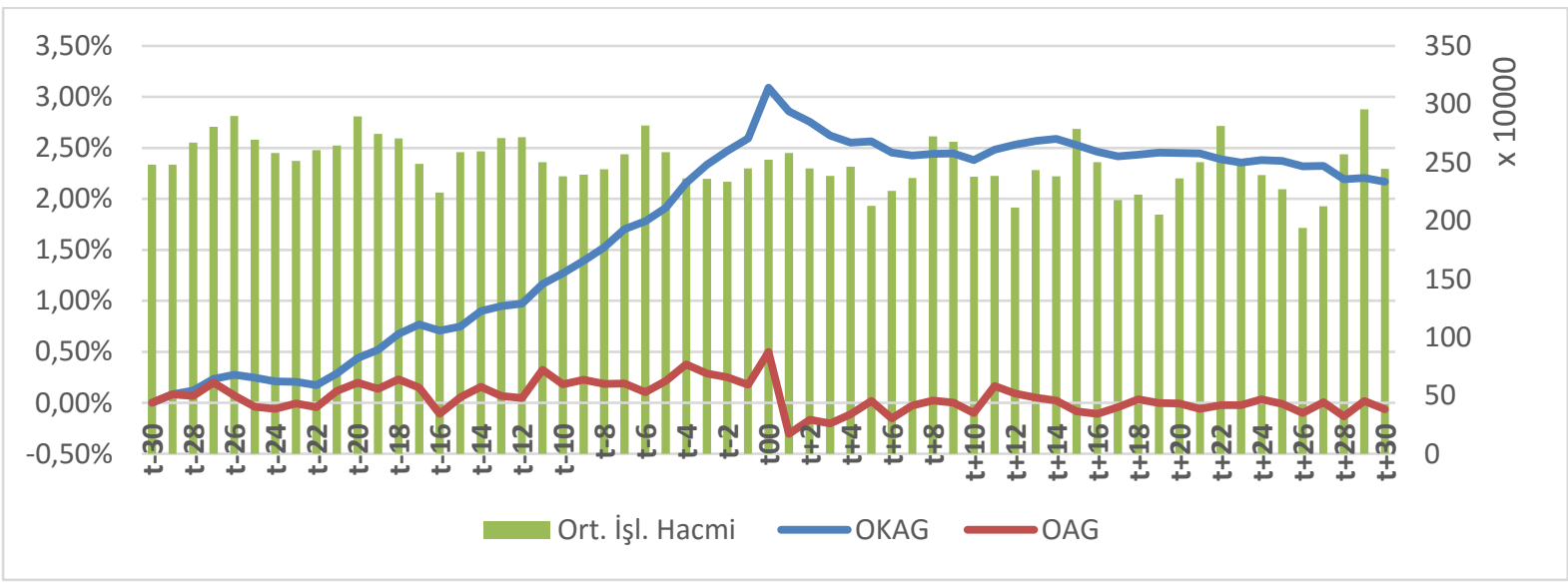

Şekil 1'den de görüleceği üzere temettü dağıtma kararını açıklamış şirket hisselerinin fiyatlarının temettüsüz günün 30 gün öncesinden artmaya başladığı ve bu artışın temettüsüz gün dahil olmak üzere devam ettiği görülmektedir. Temettüsüz günden sonra fiyatlar bir miktar düşse de öncesine göre daha yüksek bir seviyede kaldığı görülmektedir. 
Tablo 2'de, temettüsüz günden önceki 30'uncu günden başlayarak izleyen günlerdeki ortalama anormal getiriye ilişkin istatistiki özet bilgilere yer verilmektedir.

Tablo 2: Ortalama Anormal Getiriye İlişkin Tanımlayıcı İstatistikler

\begin{tabular}{cccccc}
\hline Gün & Ort. (\%) & Med. (\%) & St. Sap. (\%) & Maks. (\%) & Min. (\%) \\
\hline$t_{-29}$ & 0,08 & $-0,09$ & 2,77 & 22,19 & $-17,94$ \\
$t_{-25}$ & $-0,04$ & $-0,10$ & 2,92 & 20,33 & $-19,91$ \\
$t_{-20}$ & 0,20 & $-0,07$ & 2,62 & 20,46 & $-11,33$ \\
$t_{-15}$ & 0,05 & $-0,14$ & 2,65 & 18,65 & $-16,79$ \\
$t_{-10}$ & 0,18 & 0,03 & 2,55 & 21,83 & $-15,20$ \\
$t_{-5}$ & 0,21 & 0,10 & 2,47 & 18,25 & $-20,39$ \\
$t_{-3}$ & 0,29 & 0,10 & 2,57 & 15,82 & $-15,07$ \\
$t_{-2}$ & 0,25 & 0,08 & 2,90 & 19,55 & $-16,41$ \\
$t_{-1}$ & 0,18 & 0,16 & 2,56 & 18,52 & $-18,88$ \\
$t_{0}$ & 0,50 & 0,37 & 3,11 & 26,92 & $-20,92$ \\
$t_{+1}$ & $-0,30$ & $-0,35$ & 2,57 & 22,64 & $-21,65$ \\
$t_{+2}$ & $-0,17$ & $-0,34$ & 2,54 & 20,37 & $-19,00$ \\
$t_{+3}$ & $-0,20$ & $-0,34$ & 2,62 & 21,36 & $-14,12$ \\
$t_{+5}$ & 0,02 & $-0,18$ & 2,68 & 23,75 & $-18,89$ \\
$t_{+10}$ & $-0,10$ & $-0,20$ & 2,56 & 19,59 & $-19,01$ \\
$t_{+15}$ & $-0,08$ & $-0,16$ & 2,22 & 16,30 & $-14,86$ \\
$t_{+20}$ & $-0,01$ & $-0,20$ & 2,31 & 13,43 & $-16,13$ \\
$t_{+25}$ & $-0,01$ & $-0,21$ & 2,41 & 16,86 & $-9,82$ \\
$t_{+30}$ & $-0,06$ & $-0,16$ & 2,41 & 18,49 & $-18,23$ \\
\hline
\end{tabular}

Tablo 2'de yer alan maksimum ve minimum ortalama anormal getirilerden verinin uç değerler taşımadığı anlaşımaktadır. Şöyle ki; Borsa'da bir seansta maksimum fiyat değişikliğinin \%10 ile sınırlandırıldığı, dolayısıyla iki seansta toplam \%22 civarında artışın söz konusu olabildiği dikkate alındığında anormal getirilerin bu sınırlara seyretmesi, verinin uç değerler taşımadığını göstermektedir.

Şekil 1 ve Tablo 2'den de görüldüğüü üzere, 422 adet hisse senedinin ortalama anormal getirisi, temettüsüz gün ve öncesindeki 30 günün $25^{\prime}$ inde sıfırın üzerindedir. Temettüsüz günden sonra ise 30 günün 19'unda ortalama anormal getiri sıfırın altındadır.

Tablo 3'de temettü dağıtmanın hisse senedi fiyatı üzerine olan etkisini ölçmek üzere temettüsüz günü içerecek şekilde farklı genişlikte pencerelere ait ortalama kümülatif anormal getiriye ilişkin özet istatistikleri yer almaktadır.

Tablo 3: Olay Penceresi Bazında Ortalama Kümülatif Anormal Getiriye İlişkin Tanımlayıcı İstatistikler

\begin{tabular}{ccccccc}
\hline Olay Penceresi & Ort. (\%) & Med. (\%) & St. Sap. (\%) & Maks. (\%) & Min. (\%) & $\begin{array}{c}\text { Gün Başına } \\
\text { Düşen Getiri }\end{array}$ \\
\hline$\left(t_{-30}-t_{0}\right]$ & 3,09 & 1,89 & 12,62 & 108,43 & $-81,51$ & 0,10 \\
{$\left[t_{-25}-t_{0}\right]$} & 2,82 & 1,81 & 11,65 & 108,27 & $-72,00$ & 0,11 \\
{$\left[t_{-20}-t_{0}\right]$} & 2,80 & 1,58 & 10,27 & 109,39 & $-53,37$ & 0,13 \\
{$\left[t_{-15}-t_{0}\right]$} & 2,38 & 1,41 & 8,96 & 93,54 & $-42,50$ & 0,15 \\
{$\left[t_{-10}-t_{0}\right]$} & 1,93 & 1,33 & 7,28 & 92,12 & $-40,62$ & 0,18 \\
{$\left[t_{-5}-t_{0}\right]$} & 1,31 & 0,92 & 5,45 & 69,78 & $-39,64$ & 0,22 \\
{$\left[t_{-3}-t_{0}\right]$} & 0,93 & 0,70 & 4,67 & 35,03 & $-39,64$ & 0,23 \\
{$\left[t_{-2}-t_{0}\right]$} & 0,76 & 0,54 & 4,31 & 39,87 & $-39,64$ & 0,25 \\
{$\left[t_{0}\right]$} & 0,50 & 0,37 & 3,11 & 26,92 & $-20,92$ & 0,50 \\
{$\left[t_{1}-t_{+2}\right]$} & $-0,43$ & $-0,51$ & 3,35 & 20,85 & $-31,40$ & $-0,22$ \\
{$\left[t_{1}-t_{+3}\right]$} & $-0,47$ & $-0,54$ & 3,59 & 26,39 & $-36,20$ & $-0,16$ \\
{$\left[t_{1}-t_{+5}\right]$} & $-0,53$ & $-0,71$ & 4,82 & 63,29 & $-60,71$ & $-0,11$ \\
{$\left[t_{1}-t_{+10}\right]$} & $-0,71$ & $-1,00$ & 6,97 & 79,58 & $-64,40$ & $-0,07$ \\
{$\left[t_{1}-t_{+15}\right]$} & $-0,57$ & $-0,99$ & 8,23 & 71,58 & $-68,27$ & $-0,04$ \\
{$\left[t_{1}-t_{+20}\right]$} & $-0,64$ & $-1,11$ & 9,22 & 74,84 & $-66,41$ & $-0,03$ \\
{$\left[t_{1}-t_{+25}\right]$} & $-0,72$ & $-1,31$ & 10,20 & 63,65 & $-71,61$ & $-0,03$ \\
{$\left[t_{1}-t_{+30}\right]$} & $-0,92$ & $-1,52$ & 11,16 & 65,85 & $-82,59$ & $-0,03$
\end{tabular}




$\begin{array}{lllcccc}{\left[t_{-3}-t_{+3}\right]} & 0,47 & 0,29 & 5,87 & 44,15 & -61,29 & 0,07 \\ {\left[t_{-5}-t_{+5}\right]} & 0,78 & 0,43 & 7,27 & 65,30 & -100,35 & 0,07 \\ {\left[t_{-10}-t_{+10}\right]} & 1,22 & 0,54 & 9,63 & 86,10 & -78,81 & 0,06 \\ {\left[t_{-15}-t_{+15}\right]} & 1,82 & 0,66 & 12,11 & 127,98 & -76,63 & 0,06 \\ {\left[t_{-20}-t_{+20}\right]} & 2,16 & 0,84 & 13,94 & 140,65 & -70,59 & 0,05 \\ {\left[t_{-25}-t_{+25}\right]} & 2,10 & 0,78 & 15,81 & 124,86 & -84,09 & 0,04 \\ \left(t_{-30}-t_{+30}\right] & 2,17 & 1,03 & 17,25 & 124,35 & -101,32 & 0,04\end{array}$

Not: Olay pencerelerinde "[" ve "]" köşeli parantezleri, o günün olay penceresine dahil olduğunu, "(" parantezi ise o günün penceresine dahil olmadığını göstermektedir.

Kamuya açıklanmış bir bilgi olan temettüsüz günün öncesindeki 30 günlük sürede (( $\left.\left.t_{-30}-t_{0}\right]\right)$ kümülatif olarak ortalama $\% 3,09$ oranında Borsa endeksi üzerinde getiri sağlanmaktadır. Temettüsüz günün sonrasındaki 30 günlük sürede $\left(\left(t_{0}-t_{+30}\right]\right)$ ise kümülatif olarak ortalama $\% 0,92$ oranında Borsa endeksi altında getiri oluşmaktadır. Toplam 60 günlük olay penceresinde ([ $t$. $\left.30-t_{+30}\right]$ ) kümülatif olarak ortalama \%2,17 oranında Borsa endeksi üzerinde getiriye neden olmaktadır. Temettüsüz güne yaklaştıkça gün başına düşen ortalama kümülatif anormal getiri artmaktadır. Gün başına en yüksek ortalama kümülatif getiri temettüsüz işlem gününde $\left(\left[t_{0}\right]\right) \% 0,5$ olarak gerçekleşmektedir. Temettüsüz günden sonraki ilk günler en yüksek negatif getirinin yaşandığı günler olarak karşımıza çıkmaktadır. Gün başına en düşük ortalama kümülatif anormal getiri temettüsüz günü izleyen iki günde $\left.\left(t_{0}-t_{+2}\right]\right) \% 0,22$ olarak gerçekleşmektedir.

Tablo 3'te yer alan kümülatif anormal getirilerin istatistiki olarak sıfırdan farklı olup olmadığını test etmek üzere (6) numaralı denklemde yer alan parametrik test olan t-testi kullanılmış olup, olay penceresi bazında sonuçlar Tablo 4'te verilmiştir.

Tablo 4: Olay Penceresi Bazında Ortalama Kümülatif Anormal Getiriye ilişkin T-İstatistik Analiz Sonuçları

\begin{tabular}{cccc}
\hline Olay penceresi & OKAG (\%) & St. Sap. & t-istat. \\
\hline$\left(t_{-30}-t_{0}\right]$ & 3,09 & 12,62 & $11,67^{* * *}$ \\
{$\left[t_{-25}-t_{0}\right]$} & 2,82 & 11,65 & $11,54^{* * *}$ \\
{$\left[t_{-20}-t_{0}\right]$} & 2,80 & 10,27 & $13,02^{* * *}$ \\
{$\left[t_{-15}-t_{0}\right]$} & 2,38 & 8,96 & $12,68^{* * *}$ \\
{$\left[t_{-10}-t_{0}\right]$} & 1,93 & 7,28 & $12,61^{* * *}$ \\
{$\left[t_{-5}-t_{0}\right]$} & 1,31 & 5,45 & $11,46^{* * *}$ \\
{$\left[t_{-3}-t_{0}\right]$} & 0,93 & 4,67 & $9,55^{* * *}$ \\
{$\left[t_{-2}-t_{0}\right]$} & 0,76 & 4,31 & $8,36^{* * *}$ \\
{$\left[t_{0}\right]$} & 0,50 & 3,11 & $7,62^{* * *}$ \\
{$\left[t_{1}-t_{+2}\right]$} & $-0,43$ & 3,35 & $-5,44^{* * *}$ \\
{$\left[t_{1}-t_{+3}\right]$} & $-0,47$ & 3,59 & $-6,25^{* * *}$ \\
{$\left[t_{1}-t_{+5}\right]$} & $-0,53$ & 4,82 & $-5,22^{* * *}$ \\
{$\left[t_{1}-t_{+10}\right]$} & $-0,71$ & 6,97 & $-4,87^{* * *}$ \\
{$\left[t_{1}-t_{+15}\right]$} & $-0,57$ & 8,23 & $-3,27^{* * *}$ \\
{$\left[t_{1}-t_{+20}\right]$} & $-0,64$ & 9,22 & $-3,33^{* * *}$ \\
{$\left[t_{1}-t_{+25}\right]$} & $-0,72$ & 10,20 & $-3,35^{* * *}$ \\
{$\left[t_{1}-t_{+30}\right]$} & $-0,92$ & 11,16 & $-3,94^{* * *}$ \\
{$\left[t_{-3}-t_{+3}\right]$} & 0,47 & 5,87 & $3,79^{* * *}$ \\
{$\left[t_{-5}-t_{+5}\right]$} & 0,78 & 7,27 & $5,13^{* * *}$ \\
{$\left[t_{-10}-t_{+10}\right]$} & 1,22 & 9,63 & $6,02^{* * *}$ \\
{$\left[t_{-15}-t_{+15}\right]$} & 1,82 & 12,11 & $7,15^{* * *}$ \\
{$\left[t_{-20}-t_{+20}\right]$} & 2,16 & 13,94 & $7,39^{* * *}$ \\
{$\left[t_{-25}-t_{+25}\right]$} & 2,10 & 15,81 & $6,34^{* * *}$ \\
$\left(t_{-30}-t_{+30}\right]$ & 2,17 & 17,25 & $5,99^{* * *}$ \\
\hline
\end{tabular}

Not: ${ }^{* *} \% 1$ düzeyince istatistiki anlamlılığı göstermektedir. Olay pencerelerinde "[" ve "]" köşeli parantezleri, o günün olay penceresine dahil olduğunu, "(" parantezi ise o günün penceresine dahil olmadığını göstermektedir.

Tablo 4'te 1997-2018 yılları arasında 422 şirketin dağıttığı 2.266 adet temettünün hisse senedi getirileri üzerindeki temettüsüz gün etkisini ölçmek üzere farklı olay penceresindeki ortalama kümülatif anormal getirinin sıfırdan farklı olup olmadığına ilişkin 
t-testi sonuçları yer almaktadır. Temettüsüz günün hisse senedi getirileri üzerindeki etkisini ölçmek üzere olay gününden önceki 30 gün ve sonraki 30 günü kapsayan olay pencerelerinin tamamında t istatistiği \%1 düzeyinde anlamlıdır.

Temettüsüz gün öncesindeki 30 günlük sürede $\left(\left(t_{-30}-t_{0}\right]\right) \% 3,09$ oranında ortalama kümülatif anormal getiri sağlaması istatistiksel olarak \%1 düzeyinde anlamlıdır. Temettüsüz günü izleyen 30 günlük sürede $\left(\left(t_{0}-t_{+30}\right]\right)$ ise $\% 0,92$ oranında ortalama kümülatif anormal getiri sağlaması da istatistiksel olarak \%1 düzeyinde anlamlıdır. Toplam 60 günlük olay penceresinde ([ $t_{-30}$ - $\left.t_{+30}\right]$ ) \%2,17 oranında ortalama kümülatif anormal getiri sağlaması istatistiksel olarak \%1 düzeyinde anlamlıdır. Diğer bir ifadeyle temettü dağıtacağı belli olan hisse senedine yatırım yapılması, dağıtılan temettünün yanı sıra diğer hisse senetlerine göre ekstra \%2,17 oranında ortalama kümülatif anormal getiri sağlamaktadır.

Daha önce kamuya açıklanmış bir bilgi olan temettüsüz günde hissenin nakit temettüden daha az değer kaybettiği yapılan çalışmalarda sıkça görülmektedir. Temettüsüz günün öncesinde anormal getirinin olmasını piyasa anomalisiyle veya piyasanın etkin olmayışıla açıklamak mümkündür. Temettüsüz gün öncesi ortaya çıkan anormal getiriye benzer bir durum olan bedelsiz hisse dağıtma günü analizinde Dhatt et al. (1994) tarafından da ortaya konmuştur. Aynı şekilde Al-Yahyaee (2014) ve Woolridge (1983) bedelsiz hisse dağıtma günü anormal getirinin olduğunu tespit etmişlerdir. Temettüsüz günün öncesi ve sonrasında sırasıyla pozitif ve negatif anormal getiri tespitimiz diğer çalışmalarla uyumludur (Ainsworth et al., 2018; Grinblatt et al., 1984; Oran \& Özkan, 2001; Paudel et al., 2019; Tran, 2017; Yilmaz \& Gulay, 2006).

Temettünün büyüklüğünün ortalama kümülatif anormal getiriyi etkileyip etkilemediğini test etmek üzere nakit temettüler \%100 oranı eşik değer kabul edilerek iki guruba ayrılmıştır. \%100 oranın altında dağıtılan temettü sayısı 1.878 ve bu oranın üstünde dağıtılan temettü sayısı ise 388' dir. Aşağıdaki grafikte, bu iki grubun ortalama kümülatif anormal getirileri verilmiştir.

\section{Şekil 2: Hisse Başına Temettü Büyüklüğünün Ortalama Kümülatif Getiri Üzerine Etsisi}

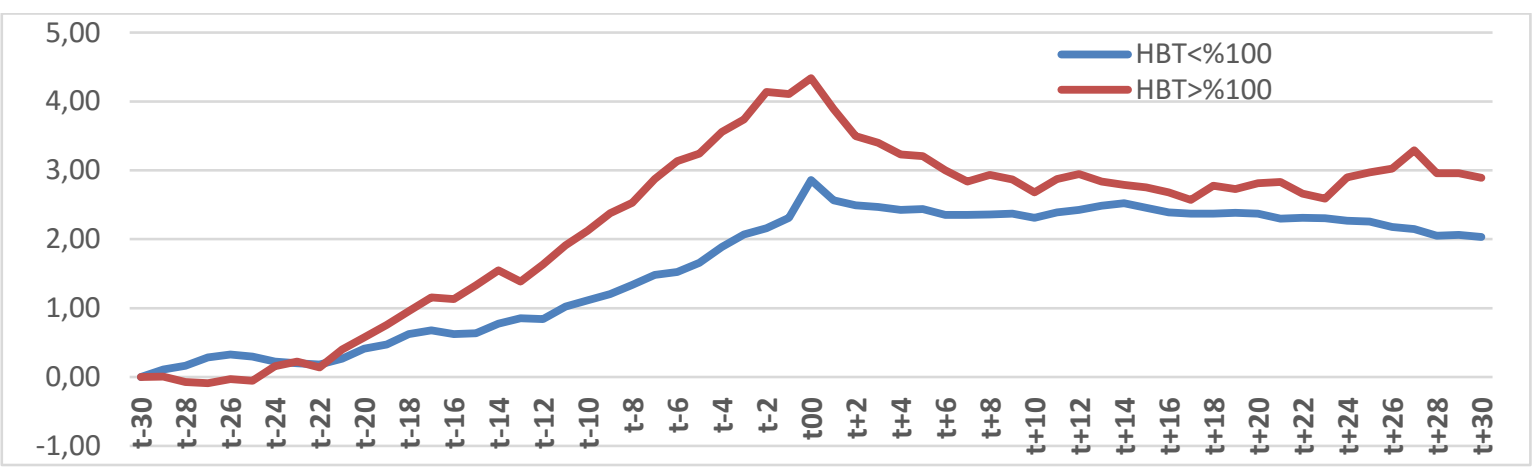

İki farklı gruba ayrılan temettülerin ortalama kümülatif anormal getirisini gösteren grafikten, $\% 100$ 'den daha büyük oranda temettü dağıtan şirketlerin özellikle [ $t_{-22}$ to $\left.t_{0}\right]$ ve $\left(t_{0}\right.$ to $t_{+10}$ ] pencerelerinde diğer guruba göre sırasıyla önce pozitif sonra negatif olmak daha yüksek ortalama kümülatif anormal getiriye neden olduğu görülmektedir. Bu farklılaşmaya ilişkin t-testi sonuçları 5 numaralı tabloda verilmektedir.

Tablo 5: Temettü Büyüklüğüne Göre Gruplara Ayrılan OKAG'ların T-İstatistik Sonuçları

\begin{tabular}{ccccccc}
\hline Windows & \multicolumn{3}{c}{ HBT<\%100 } & \multicolumn{2}{c}{ HBT>\%100 } & \multicolumn{2}{c}{ Fark } \\
\hline & OKAG & t-istat. & OKAG & t-istat. & CAAR & t-istat. \\
\hline$\left(t_{-30}-t_{0}\right]$ & 2,86 & $10,51^{* * *}$ & 4,34 & $5,33^{*}$ & $-1,48$ & $-2,03^{* * *}$ \\
{$\left[t_{-25}-t_{0}\right]$} & 2,54 & $10,25^{* * *}$ & 4,37 & $5,53^{* * *}$ & $-1,83$ & $-2,72^{* * *}$ \\
{$\left[t_{-20}-t_{0}\right]$} & 2,59 & $11,90^{* * *}$ & 3,94 & $5,53^{* * *}$ & $-1,35$ & $-2,26^{* *}$ \\
{$\left[t_{-15}-t_{0}\right]$} & 2,24 & $11,79^{* * *}$ & 3,21 & $5,01^{* * *}$ & $-0,97$ & $-1,85^{* *}$ \\
{$\left[t_{-10}-t_{0}\right]$} & 1,84 & $11,65^{* * *}$ & 2,42 & $4,97^{* * *}$ & $-0,59$ & $-1,37$ \\
{$\left[t_{-5}-t_{0}\right]$} & 1,34 & $11,51^{* * *}$ & 1,21 & $3,13^{* * *}$ & 0,13 & 0,41 \\
{$\left[t_{-3}-t_{0}\right]$} & 0,97 & $9,75^{* * *}$ & 0,78 & $2,41^{* * *}$ & 0,19 & 0,70 \\
{$\left[t_{-2}-t_{0}\right]$} & 0,79 & $8,57^{* * *}$ & 0,60 & $1,97^{* *}$ & 0,19 & 0,76 \\
{$\left[t_{-1}-t_{0}\right]$} & 0,70 & $8,88^{* * *}$ & 0,20 & 0,72 & 0,50 & $2,29^{* *}$ \\
{$\left[t_{0}\right]$} & 0,55 & $8,28^{* * *}$ & 0,23 & 1,04 & 0,31 & $1,72^{* *}$ \\
{$\left[t_{1}-t_{+1}\right]$} & $-0,29$ & $-4,86^{* * *}$ & $-0,45$ & $-2,13^{* *}$ & 0,16 & 0,95 \\
{$\left[t_{1}-t_{+2}\right]$} & $-0,37$ & $-4,51^{* * *}$ & $-0,84$ & $-3,25{ }^{* * *}$ & 0,47 & $2,16^{* *}$ \\
{$\left[t_{1}-t_{+3}\right]$} & $-0,39$ & $-5,04^{* * *}$ & $-0,94$ & $-3,80^{* * *}$ & 0,55 & $2,61^{* * *}$
\end{tabular}




\begin{tabular}{|c|c|c|c|c|c|c|}
\hline$\left[t_{1}-t_{+5}\right]$ & $-0,42$ & $-3,93^{* * *}$ & $-1,13$ & $-3,88^{* * *}$ & 0,71 & $2,54^{* * *}$ \\
\hline$\left[t_{1}-t_{+10}\right]$ & $-0,55$ & $-3,57^{* * *}$ & $-1,66$ & $-3,87^{* * *}$ & 1,11 & $2,73^{* * *}$ \\
\hline$\left[t_{1}-t_{+15}\right]$ & $-0,40$ & $-2,20^{* *}$ & $-1,59$ & $-3,27^{* * *}$ & 1,18 & $2,46^{* * *}$ \\
\hline$\left[t_{1}-t_{+20}\right]$ & $-0,49$ & $-2,37^{* * *}$ & $-1,52$ & $-2,74^{* * *}$ & 1,04 & $1,92^{* *}$ \\
\hline$\left[t_{1}-t_{+25}\right]$ & $-0,60$ & $-2,64^{* * *}$ & $-1,37$ & $-2,26^{* *}$ & 0,77 & 1,28 \\
\hline$\left[t_{1}-t_{+30}\right]$ & $-0,82$ & $-3,31^{* * *}$ & $-1,45$ & $-2,15^{* *}$ & 0,62 & 0,95 \\
\hline
\end{tabular}

İki farklı gruba ayrılan temettülerin ortalama kümülatif anormal getirilerine ilişkin getiri farkı t-testi sonuçları, iki grubun ortalama kümülatif anormal getirileri arasında fark olduğunu ve bu farkların istatistiksel olarak anlamlı düzeylerde olduğunu ortaya koymaktadır. \%100'den daha yüksek oranda temettü dağıtan şirketlerin temettüsüz güne kadar diğer gruba göre daha yüksek pozitif getiriye neden olduğu, diğer guruba göre sırasıyla önce pozitif sonra negatif olmak üzere daha yüksek ortalama kümülatif anormal getiriye neden olduğu görülmektedir. Bedelsiz hisse senedi temettülerinin dağıtma etkisini analiz eden Grinblatt et al. (1984) tarafından yapılan çalışmada da benzer sonuca ulaşılmıştır.

1997-2018 yılları arasında 422 şirketin dağıttığı 2.266 adet nakit temettünün hisse senedi getirileri üzerindeki temettüsüz gün etkisi yarattığı ve daha yüksek temettü dağıtımı olan payın daha yüksek getiri sağladığı sonucundan yola çıkarak aşağıdaki yatırım stratejisinin geliştirilmesi mümkündür.

Tablo 6: Temettüsüz Gün Bazlı Yatırım Stratejisi

\begin{tabular}{cccccc}
\hline \multirow{2}{*}{ Hisse } & Aksiyon 1 & \multicolumn{2}{c}{ Aksiyon 2 } & Potansiyel Kar \\
\hline \multirow{2}{*}{$\mathrm{HBT}>\% 100$} & Al/Sat & Zaman & Al/Sat & Zaman & \\
& Al & $\mathrm{t}_{-12}$ & Sat & $\mathrm{t}_{0}$ & $\% 2,96$ \\
& Açığa Sat & $\mathrm{t}_{0}$ gün sonu & Al & $\mathrm{t}_{+7}$ & $\% 1,51$ \\
\hline
\end{tabular}

Hisse başına \%100'den daha yüksek oranda temettü dağıtmaya karar vermiş olan şirketin hisse senedinin $\mathrm{t}_{-22}$ 'nci günden itibaren hızla artmaya bağladığı dikkate alındığında, bu tarihten temettüsüz güne kadar olan sürede oluşan \%4,20'lik artışın \%70'ni kapsayacak şekilde alım yönünde yatırım stratejisi geliştirmenin mümkün olduğu anlaşılmaktadır. Benzer şekilde temettüsüz günden sonraki ilk 7 günde hisse başına $\% 100$ 'den daha yüksek oranda temettü dağıtmaya karar vermiş olan şirketin hisse senedinin fiyatının hızlı bir şekilde düştüğü dikkate alınarak bu dönemde açığa satış şeklinde yatırım stratejisi geliştirmek mümkündür.

Hisse başına \%100 oranından daha fazla temettü dağıtacağını açıklayan şirket hisselerinin, ilk aşamada temettüsüz gününün 12 gün öncesinde satın alınması ve temettüsüz günün sonunda satılması durumunda, hisseye verilen nakit kâr payına ek olarak 13 günde ortalama \%2,96 anormal getiri elde edildiği ve ikinci aşamada temettüsüz günün sonunda aynı hisse senedinin açığa satılması ve 7 gün sonra geri satın alınması durumunda 7 günde ortalama \%1,51 anormal getiri elde edildiği hesaplanmıştır. Dolayısıyla, nakit temettü dağıtım sürecindeki anomaliden yararlanarak hisse başına \%100'ün üzerinde nakit temettüye ek olarak 20 günde ortalama \%4,47 oranında piyasa endeks getirisinin üzerinde getiri sağlanabilmektedir.

\section{SONUÇ}

Daha önce kamuya açıklanmış olan, nakit kâr payı dağıtım süresi sonunda piyasa fiyatı ile temettüsü düşülmüş teorik fiyat arasındaki farkın temettüsüz günün öncesi ve sonrasında anormal getiriye sebep olduğu çeşitli çalışmalarda ortaya konmuş olmakla birlikte, bu anomalinin neden oluştuğuna ilişkin teorik ve ampirik açıklamalar hala kesin bir sonuca varamamıştır.

Bu çalışmada, nakit temettüden kaynaklanan temettüsüz günün öncesi ve sonrasında anormal getirinin olup olmadığı Türkiye için test edilmiş ve bu anomalinin bir yatırım stratejisine dönüştürülme imkanın olup olmadığı araştırılmıştır. Bu amaçla Borsa İstanbul'da işlem gören 422 farklı şirketin 1997-2018 yılları arasındaki 2.266 adet nakit temettü ve bu kar paylarının temettüsüz günlerini içerecek şekilde düzeltilmiş fiyat ve endeks verileri kullanılarak, temettüsüz günün öncesi ve sonrasında 30 'ar günlük olay pencereleri açılarak anormal getiriler olay analizi yöntemi ile incelenmiştir.

Yapılan analiz sonuçlarına göre temettüsüz günün öncesindeki 30 günlük sürede $\% 3,09$ oranında ortalama kümülatif anormal getiri ve temettüsüz günün sonrası 30 günlük sürede ise $\% 0,92$ oranında negatif ortalama kümülatif anormal getiri sağlandığı ve bunun istatistiksel olarak \%1 düzeyinde anlamlı olduğu görülmüştür. Toplam 60 günlük olay penceresinde $\% 2,17$ oranında ortalama kümülatif anormal getiri elde edilmektedir. Diğer bir ifade ile, temettü hak bitimi belli olan hisse senedine yatırım yapılması, diğer hisse senetlerine göre dağıtılan temettünün yanı sıra ekstra \%2,17 oranında ortalama kümülatif anormal getiri sağlamaktadır. Bulgularımız daha önceki literatürle büyük ölçüde uyumludur. 
Çalışmamızdaki bulgular kapsamında, temettü hak bitiminden kaynaklanan fiyat anomalisinin birbirinden bağımsız iki aşamalı yatırım stratejisi olarak kullanılabileceği sonucuna ulaşılmışır. Hisse başına \%100 oranından daha fazla temettü dağıtacağını açıklayan şirket hisselerinin, ilk aşamada temettüsüz gününün 12 gün öncesinde satın alınması ve temettüsüz günün sonunda satılması durumunda, hisseye verilen nakit kâr payına ek olarak 13 günde ortalama \%2,96 anormal getiri elde edildiği ve ikinci aşamada temettüsüz günün sonunda aynı hisse senedinin açığa satılması ve 7 gün sonra geri satın alınması durumunda 7 günde ortalama \%1,51 anormal getiri elde edildiği hesaplanmıştır. Dolayısıyla, nakit temettü dağıtım sürecindeki anomaliden yararlanarak hisse başına $\% 100$ 'ün üzerinde nakit temettüye ek olarak 20 günde ortalama $\% 4,47$ oranında piyasa endeks getirisinin üzerinde getiri sağlanabilmektedir.

\section{REFERENCES}

Aharony, J., \& Swary, I. (1980). Quarterly dividend and earnings announcements and stockholders' returns: An empirical analysis. The Journal of Finance, 35(1), 1. doi:10.2307/2327176

Ainsworth, A. B., Fong, K. Y. L., Gallagher, D. R., \& Partington, G. (2018). Taxes, order imbalance and abnormal returns around the ex-dividend day. International Review of Finance, 18(3), 379-409. doi:10.1111/irfi.12155

Akhigbe, A., \& Madura, J. (1996). Dividend policy and corporate performance. Journal of Business Finance \& Accounting, 23(9-10), $1267-1287$. doi:10.1111/1468-5957.00079

Al-Yahyaee, K. H. (2014). Stock dividend ex-day effect and market microstructure in a unique environment. International Economics, 139, 7179. doi:10.1016/j.inteco.2014.04.002

Armitage, S. (1995). Event study methods and evidence on their performance. Journal of Economic Surveys, 9(1), 25-52. doi:10.1111/j.14676419.1995.tb00109.x

Asquith, P., \& Mullins, J. D. W. (1983). The impact of initiating dividend payments on shareholders' wealth. The Journal of Business, 56(1), 7796. doi:10.1086/296187

Aydogan, K., \& Muradoglu, G. (1998). Do markets learn from experience?: Price reaction to stock dividends in the turkish market. Applied Financial Economics, 8(1), 41-49. doi:10.1080/096031098333230

Ball, R., \& Brown, P. (1968). An empirical evaluation of accounting income numbers. Journal of accounting research, $159-178$.

Barclay, M. J. (1987). Dividends, taxes, and common stock prices: The ex-dividend day behavior of common stock prices before the income tax. Journal of Financial Economics, 19(1), 31-44. doi:10.1016/0304-405X(87)90027-4

Basdas, U., \& Oran, A. (2014). Event studies in turkey. Borsa Istanbul Review, 14(3), 167-188. doi:10.1016/j.bir.2014.03.003

Batchelor, R., \& Orakcioglu, I. (2003). Event-related garch: The impact of stock dividends in turkey. Applied Financial Economics, 13(4), 295307. doi:10.1080/09603100210138547

Boyd, J. H., \& Jagannathan, R. (1994). Ex-dividend price behavior of common-stocks. Review of Financial Studies, 7(4), 711-741. doi:10.1093/rfs/7.4.711

Brown, S. J., \& Warner, J. B. (1980). Measuring security price performance. Journal of Financial Economics, 8(3), 205-258. doi:10.1016/0304$405 \times(80) 90002-1$

Campbell, J. Y., Lo, A. W., \& MacKinlay, A. C. (1997). The econometrics of financial markets (Vol. 2): princeton University press Princeton, NJ.

Charest, G. (1978). Dividend information, stock returns and market efficiency-ii. Journal of Financial Economics, 6(2), 297-330. doi:10.1016/0304-405X(78)90033-8

Chottiner, S., \& Young, A. (1971). A test of the aicpa differentiation between stock dividends and stock splits. Journal of accounting research, 367-374. doi:10.2307/248994

Chowdhury, J., \& Sonaer, G. (2016). Ex-dividend day abnormal returns for special dividends. Journal of Economics and Finance, 40(4), 631652. doi:10.1007/s12197-015-9317-7

Dennis, D. K., \& McConnell, J. J. (1986). Corporate mergers and security returns. Journal of Financial Economics, 16(2), $143-187$. doi:10.1016/0304-405X(86)90059-0

Dhatt, M. S., Kim, Y. H., \& Mukherji, S. (1994). Japanese stock price reactions to stock dividend distributions. Pacific-Basin Finance Journal, 2(1), 43-59. doi:10.1016/0927-538X(94)90028-0

Dhatt, M. S., Kim, Y. H., \& Mukherji, S. (1996). Is the stock dividend ex-day effect due to market microstructure?: Contrary evidence from korea. Global Finance Journal, 7(1), 89-99. doi:10.1016/S1044-0283(96)90015-0

Dimpfl, T. (2011). The impact of us news on the german stock market-an event study analysis. The Quarterly Review of Economics and 
Finance, 51(4), 389-398. doi:10.1016/j.qref.2011.07.005

Dolley, J. C. (1933). Characteristics and procedure of common stock split-ups. Harvard Business Review, 11(3), 316-326.

Dubofsky, D. A. (1992). A market microstructure explanation of ex-day abnormal returns. Financial Management, 21(4), 32-43. doi:10.2307/3665839

Dupuis, D. (2019). Ex-dividend day price behavior and liquidity in a tax-free emerging market. Emerging Markets Review, $38,239-250$. doi:10.1016/j.ememar.2019.02.001

Eades, K. M., Hess, P. J., \& Kim, E. H. (1984). On interpreting security returns during the ex-dividend period. Journal of Financial Economics, 13(1), 3-34. doi:10.1016/0304-405X(84)90030-8

Elton, E. J., \& Gruber, M. J. (1970). Marginal stockholder tax rates and the clientele effect. The Review of Economics and Statistics, 52(1), 6874. doi:10.2307/1927599

Elton, E. J., Gruber, M. J., \& Blake, C. R. (2005). Marginal stockholder tax effects and ex-dividend-day price behavior: Evidence from taxable versus nontaxable closed-end funds. Review of Economics and Statistics, 87(3), 579-586. doi:10.1162/0034653054638337

Fatemi, A., \& Bildik, R. (2012). Yes, dividends are disappearing: Worldwide evidence. Journal of Banking \& Finance, 36(3), 662-677. doi:10.1016/j.jbankfin.2011.10.008

Foster, T. W., \& Vickrey, D. (1978). The information content of stock dividend announcements. The Accounting Review, 53(2), 360-370.

Frank, M., \& Jagannathan, R. (1998). Why do stock prices drop by less than the value of the dividend? Evidence from a country without taxes. Journal of Financial Economics, 47(2), 161-188. doi:10.1016/S0304-405X(97)80053-0

Ghadhab, I. (2018). Arbitrage opportunities and liquidity: An intraday event study on cross-listed stocks. Journal of Multinational Financial Management, 46, 1-10. doi:10.1016/j.mulfin.2018.07.002

Graham, J. R., \& Kumar, A. (2006). Do dividend clienteles exist? Evidence on dividend preferences of retail investors. The Journal of Finance, 61(3), 1305-1336. doi:10.1111/j.1540-6261.2006.00873.x

Graham, J. R., Michaely, R., \& Roberts, M. R. (2003). Do price discreteness and transactions costs affect stock returns? Comparing ex-dividend pricing before and after decimalization. Journal of Finance, 58(6), 2611-2635. doi:10.1046/j.1540-6261.2003.00617.x

Gregory, A., Matatko, J., \& Tonks, I. (1997). Detecting information from directors' trades: Signal definition and variable size effects. Journal of Business Finance \& Accounting, 24(3), 309-342. doi:10.1111/1468-5957.00107

Grinblatt, M. S., Masulis, R. W., \& Titman, S. (1984). The valuation effects of stock splits and stock dividends. Journal of Financial Economics, 13(4), 461-490. doi:10.1016/0304-405x(84)90011-4

Günalp, B., Kadioglu, E., \& Kılıç, S. (2010). Nakit temettü bilgisinin hisse senedi getirisi üzerinde önemli bir etkisi olup olmadığının İmkb'de test edilmesi. Hacettepe Üniversitesi iibf Dergisi, 28(2), 47-69.

Hartzmark, S. M., \& Solomon, D. H. (2019). The dividend disconnect. The Journal of Finance, 74(5), 2153-2199. doi:10.1111/jofi.12785

Hillier, D., \& Marshall, A. P. (2002). Are trading bans effective? Exchange regulation and corporate insider transactions around earnings announcements. Journal of Corporate Finance, 8(4), 393-410. doi:10.1016/S0929-1199(01)00046-3

Jakob, K., \& Whitby, R. (2017). The impact of nominal stock price on ex-dividend price responses. Review of Quantitative Finance and Accounting, 48(4), 939-953. doi:10.1007/s11156-016-0574-0

Jiang, C.-H., \& Huang, Y.-S. (2009). Price clustering at the opening and closing in a call market evidence from the taiwan stock exchange. International Research Journal of Finance and Economics(31), 16-28.

Kadioglu, E., Telçeken, N., \& Öcal, N. (2015). Market reaction to dividend announcement: Evidence from turkish stock market. International Business Research, 8(9), 83-94. doi:10.5539/ ibr.v8n9p83

Kalay, A. (1982). The ex-dividend day behavior of stock prices: A re-examination of the clientele effect. The Journal of Finance, 37(4), 10591070. doi:10.2307/2327767

Karpoff, J. M., \& Walkling, R. A. (1988). Short-term trading around ex-dividend days - additional evidence. Journal of Financial Economics, 21(2), 291-298. doi:10.1016/0304-405x(88)90063-3

Kirbaş, A. (2018). Temettü duyurularının hisse senedi getirilerine olan etkilerinin analizi. Ekonomi, Politika \& Finans Araştırmaları Dergisi, 3(2), 133-148. doi:10.30784/epfad.440313

Kočenda, E., \& Moravcová, M. (2018). Intraday effect of news on emerging european forex markets: An event study analysis. Economic Systems, 42(4), 597-615. doi:10.1016/j.ecosys.2018.05.003

Koski, J. L. (1996). A microstructure analysis of ex-dividend stock price behavior before and after the 1984 and 1986 tax reform acts. Journal of Business, 69(3), 313-338. doi:10.1086/209693 
Lakonishok, J., \& Vermaelen, T. (1986). Tax-induced trading around ex-dividend days. Journal of Financial Economics, 16(3), $287-319$. doi:10.1016/0304-405X(86)90032-2

Le, N. N. A., Yin, X. K., \& Zhao, J. (2019). Effects of investor tax heterogeneity on stock prices and trading behaviour around the ex-dividend day: The case of australia. Accounting and Finance. doi:10.1111/acfi.12520

Marsh, P. (1979). Equity rights issues and the efficiency of the uk stock market. The Journal of Finance, 34(4), 839-862. doi:10.2307/2327051

Marshall, A., McCann, L., \& McColgan, P. (2018). The market reaction to debt announcements: Uk evidence surrounding the global financial crisis. The British Accounting Review, 51(1), 92-109. doi:10.1016/j.bar.2018.04.001

Michaely, R., \& Vila, J.-L. (1995). Investors' heterogeneity, prices, and volume around the ex-dividend day. The Journal of Financial and Quantitative Analysis, 30(2), 171-198. doi:10.2307/2331116

Michaely, R., \& Vila, J. L. (1996). Trading volume with private valuation: Evidence from the ex-dividend day. Review of Financial Studies, 9(2), 471-509. doi:10.1093/rfs/9.2.471

Miletić, M. (2011). Stock price reaction to dividend announcement in croatia. Economic Research-Ekonomska Istraživanja, 24(3), 147-156. doi:10.1080/1331677X.2011.11517473

Mortal, S., Paudel, S., \& Silveri, S. (2017). The impact of market structure on ex-dividend day stock price behavior. Financial Management (Wiley-Blackwell), 46(4), 1053-1082. doi:10.1111/fima.12176

Muradoğlu, G., \& Aydoğan, K. (2003). Trends in market reactions: Stock dividends and rights offerings at istanbul stock exchange. The European Journal of Finance, 9(1), 41-60. doi:10.1080/13518470110047611

Naranjo, A., Nimalendran, M., \& Ryngaert, M. (2000). Time variation of ex-dividend day stock returns and corporate dividend capture: A reexamination. Journal of Finance, 55(5), 2357-2372. doi:10.1111/0022-1082.00290

Oran, A., \& Özkan, D. (2001, 2001). Ex-dividend date behaviour without taxes. Paper presented at the Global Business and Technology Association International Conference Proceedings.

Papaioannou, G. J., Travlos, N. G., \& Tsangarakis, N. V. (2000). Valuation effects of greek stock dividend distributions. European Financial Management, 6(4), 515-531. doi:10.1111/1468-036X.00137

Paudel, S., Silveri, S., \& Wu, M. (2019). Nasdaq ex-day behavior: An out-of-sample test. Review of Financial Economics. doi:10.1002/rfe.1083

Pettit, R. R. (1972). Dividend announcements, security performance, and capital market efficiency. The Journal of Finance, $27(5), 993-1007$. doi:10.2307/2978844

Piccoli, P., Chaudhury, M., Souza, A., \& da Silva, W. V. (2017). Stock overreaction to extreme market events. The North American Journal of Economics and Finance, 41, 97-111. doi:10.1016/j.najef.2017.04.002

Sivakumar, K., \& Waymire, G. (1994). Insider trading following material news events: Evidence from earnings. Financial Management, 23(1), 23-32. doi:10.2307/3666053

Tran, Q. T. (2017). Dividend capture on the ex-dividend day: Evidence from vietnamese stock market. Asian Academy of Management Journal of Accounting and Finance, 13(2), 69-94. doi:10.21315/aamjaf2017.13.2.4

Whitworth, J., \& Rao, R. P. (2010). Do tax law changes influence ex-dividend stock price behavior? Evidence from 1926 to 2005. Financial Management, 39(1), 419-445. doi:10.1111/j.1755-053X.2010.01078.x

Woolridge, J. R. (1982). The information content of dividend changes. Journal of Financial Research, 5(3), 191. doi:10.1111/j.14756803.1982.tb00298.x

Woolridge, J. R. (1983). Dividend changes and security prices. The Journal of Finance, 38(5), 1607-1615. doi:10.1111/j.15406261.1983.tb03844.x

Yildiz, Y., Karan, M. B., \& Pirgaip, B. (2017). Market reaction to grouping equities in stock markets: An empirical analysis on borsa istanbul. Borsa Istanbul Review, 17(4), 216-227. doi:10.1016/j.bir.2017.08.001

Yilmaz, M. K., \& Gulay, G. (2006). Dividend policies and price-volume reactions to cash dividends on the stock market: Evidence from the istanbul stock exchange. Emerging Markets Finance and Trade, 42(4), 19-49. doi:10.2753/REE1540-496X420402 